\title{
INSPIREE:
}

\section{Tingkat Korelasional antara Power Otot Tungkai dan Lengan dalam Smash pada Atlet Bola Voli}

d.

https://doi.org/10.53905/inspiree.v1i3.13

"Kosharyanto Pratomo ${ }^{\text {ibcode, }}$, Muhammad Iqbal"

${ }^{1}$ Pendidikan Olahraga Pendidikan Olahraga, STKIP Kusuma Negara Jakarta, Indonesia.

Kata Kunci: power otot lengan; power otot tungkai; pukulan smash.

\section{PENDAHULUAN}

Olahraga merupakan aktivitas gerak tubuh yang selalu membuat manusia dalam keadaan sehat jiwa dan raga, dalam keadaan inilah manusia dapat mengembangkan kreatifitas untuk mencapai impian dan masa depan yang cemerlang, apalagi mengukir cita-cita melalui olahraga tentu membutuhkan tubuh yang sehat dan kuat.Peningkatan prestasi olahraga di Indonesia akhir-akhir ini, telah menunjukan perkembangan yang semakin baik. Ini dapat dimaklumi bila kita melihat partisipasi dari segala lapisan masyarakat yang telah menggalakkan kegiatan keolahragaan, demikian pula kesadaran masyarakat akan pentingnya berolahraga untuk kesehatan. Salah satu cabang olahraga yang cepat berkembang dan paling digemari oleh masyarakat saat ini adalah permainan bola voli, olahraga ini sudah sangat dikenal oleh masyarakat umum. Hal ini 
dibuktikan dengan terbentuknya berbagai klub bola voli baik pada daerah perkotaan maupun pedesaan. Klub-klub tersebut terbina dan tumbuh dengan sendirinya dikarenakan animo masyarakat yang cukup tinggi. Biasanya klub bola voli yang terdapat dalam masyarakat lebih menonjolkan olahraga yang bersifat pada pengisian waktu senggang para pemainnya.

Pada awal penemuannya, olahraga permainan bola voli ini diberi nama Mintonette. Olahraga Mintonette ini pertama kali ditemukan oleh seorang Instruktuk. pendidikan jasmani (Director of Phsycal Education) yang bernama William G. Morgan di YMCA pada tanggal 9 Februari 1895, di Holyoke, Massachusetts (Amerika Serikat). YMCA (Young Men's Christian Association) merupakan sebuah organisasi yang didedikasikan untuk mengajarkan ajaran-ajaran pokok umat Kristen kepada para pemuda. Morgan menciptakan sebuah olahraga baru yang bernama Mintonette. Sama halnya dengan James Naismith, William G. Morgan juga mendedikasikan hidupnya sebagai seorang instruktur pendidikan jasmani. William G. Morgan yang juga merupakan lulusan Springfield College of YMCA, menciptakan permainan Mintonette ini empat tahun setelah diciptakannya olahraga permainan basketball oleh James Naismith. Olahraga permainan Mintonette sebenarnya merupakan sebuah permainan yang diciptakan dengan mengkombinasikan beberapa jenis permainan. Tepatnya, permainan Mintonette diciptakan dengan mengadopsi empat macam karakter olahraga permainan menjadi satu, yaitu bola basket, baseball, tenis, dan yang terakhir adalah bola tangan (handball). Pada awalnya, permainan ini diciptakan khusus bagi anggota YMCA yang sudah tidak berusia muda lagi, sehingga permainan ini-pun dibuat tidak seaktif permainan bola basket.

Hal ini diharapkan, setiap pemain bola voli hendaknya selalu berupaya untuk meningkatkan power otot lengannya. Power otot lengan yang besar, memungkinkan hasil pukulan smash atau servisnya akan lebih keras dan cepat, sehingga tingkat keberhasilannya pun lebih besar pula. Troter mengatakan (1965) Power, or sheer force, is aquality of the service which can be developed to the extend that it makes a return of the service by the receiving team either completlely impossible or else definitely weakens the return by forcing the use of two, or three contack to bring the ball under control and tomake a return to the serving teams court Oleh karena itu, maka seorang 
pemain yang akan melakukan smash harus memiliki power otot lengan yang bagus. Kedua, terdapat hubungan yang positif dan signifikan antara otot tungkai dengan hasil smash semi pada cabang olahraga bola voli. Hal ini menunjukan bahwa otot tungkai mempunyai peran penting terhadap hasil smash. Otot tungkai yang besar akan menghasilkan lompatan yang maksimal. Seorang pemain bola voli sangat diharuskan memiliki lompatan yang setinggi mungkin untuk melakukan smash. Dijelaskan pula oleh Kosasih (1983), bahwa "Dalam melakukan smash sebaiknya kita dapat melompat setinggi mungkin, karena itu latihlah melompat sebanyak mungkin". Dengan demikian, dengan otot tungkai yang besar maka seorang smash akan semakin tinggi menjangkau bola yang diumpankan tinggi diatas net pada saat memukul bola.

Bola voli yang dikenal masyarakat juga merupakan salah satu cabang olahraga yang telah dikembangkan secara baik oleh induk olahraga itu sendiri. Bola voli telah diprogramkan dalam kurikulum pendidikan bidang studi pendidikan jasmani dan kesehatan pada seluruh lembaga pendidikan, seperti SD, SLTP dan SLTA, bahkan pada tingkat perguruan tinggi pun juga ada, misalnya di STKIP Kusumanegara Jakarta Jurusan Pendidikan Olahraga. Hal tersebut diharapkan agar cabang olahraga bola voli dapat berkembang pesat dan dikenal baik olehmasyarakat.

Permainan bola voli terdiri dari teknik dasar permainan, diantaranya: servis, umpan, smash dan block. Keseluruhan dari dasar teknik bola voli diatas sangat berperan untuk memperoleh nilai atau point bagi regu yang bertanding. Ketetapan servis merupakan nilai pertama bagi regunya, umpan berguna untuk dilanjutkan menjadi suatu serangan, sedangkan smash merupakan serangan yang paling ampuh untuk mematahkan pertahanan lawan dan block merupakan pertahanan yang paling efektif yang dilakukan didepan net oleh regu bertahan.Smash yang baik baru di peroleh apabila seorang pemain memiliki power otot tungkai, kekuatan otot perut dan power otot lengan yang baik pula. Power otot tungkai berperan pada saat seorang pemain melakukan loncatan pada saat melakukan smash. Di samping itu juga sangat dibutuhkan kekuatan otot perut. Power otot lengan berfungsi pada saat sentuhan bola dengan tangan sehingga menghasilkan power yang kuat. 


\section{METODOLOGI PENELITIAN}

\section{Study participants}

Responden penelitian adalah seluruh pemain bola voli SMA yayasan perguruan rakyat-1 yang berjumlah 20 orang, sehingga seluruh populasi dijadikan sebagai subjek penelitian.

\section{Study organization}

Suatu penelitian yang tertuju pada masalah yang timbul pada masa sekarang ini dinamakan penelitian diskriptif, Widaninggar mengatakan penelitian diskriptif tertuju pada pemecahan masalah yang ada pada masa sekarang. Sedangkan pendekatan yang digunakan untuk menjawab permasalahan adalah pendekatan korelasional, jadi penelitian ini termasuk kedalam penelitian diskriptif jenis korelasional. Arikunto berpendapat bahwa dalam penelitian korelasional, peneliti memilih individu-individu yang mempunyai variasi dalam hal yang diselidiki, semua anggota kelompok yang dipilih sebagai subjek penelitian diukur mengenai jenis variabel yang diselidiki, kemudian dihitung untuk diketahui korelasinya.

Berdasarkan pendapat diatas maka penelitian ini termasuk kedalam penelitian diskriptif korelasional, artinya penelitian ini bertujuan untuk menemukan ada atau tidaknya hubungan antara satu variabel dengan variabel yang lain. Namun sebelumnya harus dibuat rancangan atau desain penelitian agar memudahkan pelaksananan pengukuran yang dilaksanakan, dalam hal ini pengukuran lapangan. Menurut Arikunto bahwa: "rancangan penelitian atau desain penelitian adalah : rancangan yang dibuat oleh peneliti, sebagai ancang-ancang kegiatan yang kan dilaksanakan". Dapat dilihat pada gambar 1. berikut:

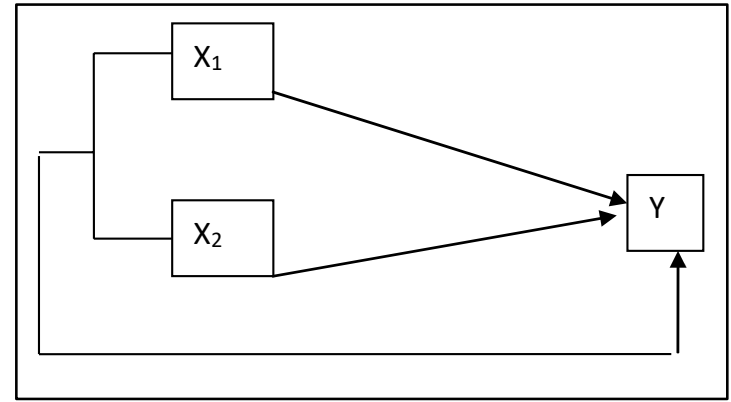

\footnotetext{
Keterangan: $\quad X_{1}=$ Pengukuran power otottungkai

$X_{2}=$ Pengukuran power otot lengan $Y=$ Tes smash
}

Gambar 1. Konstelasi Antar Korelasional Variabel 
Jadi rancangan penelitian ini yaitu mengukur power otot tungkai dan power otot lengan yang dihubungkan dengan kemampuan pukulan smash permainan bola voli.

Testing procedure.

Dalam rancangan ini langkah yang dilakukan adalah tes power otot tungkai $\left(X_{1}\right)$. Selanjutnya dilakukan tes power otot lengan $\left(\mathrm{X}_{2}\right)$. Selanjutnya dilakukan tes pukulan smash yang merupakan variable $Y$, sehingga data-data variable $X$ dapat dikorelasikan dengan variable $\mathrm{Y}$.

\section{HASIL PENELITIAN}

Data penelitian yang diperoleh dalam hasil tes yang dilakukan pada pemain bola voli SMA Yayasan Perguruan Rakyat 1 yaitu berupa kuantitatif atau data bentuk angka, data ini dapat secara langsung dari tes power otot tungkai, tes power otot lengan dan tes smash. Data-data tersebut ditabulasikan kedalam tabel dan hasilnya sebagaiberikut. Menghitung Koefesien Korelasi Antara Power Otot Tungkai $\left(\mathrm{X}_{1}\right)$ dengan Pukulan Smash (Y) Pada Pemain Bola Voli.

Tabel 1. Koefesien Korelasi Antara Power Otot Tungkai (X1) dengan Pukulan Smash (Y) Pada Pemain Bola Voli SMA Yayasan Perguruan Rakyat 1.

\begin{tabular}{|c|c|c|c|c|c|c|}
\hline No & Responden & $X_{1}$ & $x_{1}^{2}$ & $\mathbf{Y}$ & $y^{2}$ & $X_{1} Y$ \\
\hline 1 & 2 & 3 & 4 & 5 & 6 & 7 \\
\hline 1 & 1 & 56,11 & 3148,33 & 110,43 & 12194,78 & 6172,10 \\
\hline 2 & 2 & 71,99 & 5182,56 & 108,11 & 11687,77 & 7782,84 \\
\hline 3 & 3 & 45,00 & 2025,00 & 100,94 & 10188,88 & 4542,30 \\
\hline 4 & 4 & 35,48 & 1258,83 & 97,19 & 9445,90 & 3448,30 \\
\hline 5 & 5 & 35,48 & 1258,83 & 103,35 & 10681,22 & 3704,06 \\
\hline 6 & 6 & 51,35 & 2636,82 & 87,08 & 7582,93 & 4471,56 \\
\hline 7 & 7 & 40,24 & 1619,26 & 94,73 & 8973,77 & 3811,93 \\
\hline 8 & 8 & 37,10 & 1376,41 & 87,21 & 7605,58 & 3235,49 \\
\hline 9 & 9 & 52,94 & 2802,64 & 91,79 & 8425,40 & 4859,36 \\
\hline 10 & 10 & 45,00 & 2025,00 & 97,11 & 9430,35 & 4369,95 \\
\hline 11 & 11 & 54,52 & 2972,43 & 122,57 & 15023,40 & 6682,52 \\
\hline 12 & 12 & 52,94 & 2802,64 & 106,35 & 11310,32 & 5630,17 \\
\hline 13 & 13 & 54,52 & 2972,43 & 79,08 & 6253,64 & 4311,44 \\
\hline 14 & 14 & 54,52 & 2972,43 & 118,91 & 14139,59 & 6482,97 \\
\hline 15 & 15 & 57,70 & 3329,29 & 79,46 & 6313,89 & 4584,84 \\
\hline 16 & 16 & 40,24 & 1619,26 & 97,96 & 9596,16 & 3941,91 \\
\hline 17 & 17 & 54,52 & 2972,43 & 116,48 & 13567,59 & 6350,49 \\
\hline 18 & 18 & 38,65 & 1493,82 & 83,73 & 7010,71 & 3236,16 \\
\hline 19 & 19 & 64,05 & 4102,40 & 118,46 & 14032,77 & 7587,36 \\
\hline 20 & 20 & 57,70 & 3329,29 & 93,70 & 8779,69 & 5406,49 \\
\hline \multicolumn{2}{|r|}{ Jumlah } & 1000,05 & 51900,10 & 1994,64 & 202244.34 & 100812,2 \\
\hline
\end{tabular}

Dengan demikian, koefisien korelasi antara power otot tungkai $\left(\mathrm{X}_{1}\right)$ dengan pukulan smash (Y) pada pemain bola voli SMA Yayasan Perguruan Rakyat 1 adalah sebesar0,42. Dari hasil perhitungan koefesien korelasi $X_{1} Y$ diperoleh harga $r=0,42$ sehingga koefesien determinasinya adalah $(0,42) 2 \times 100 \%=17.64 \%$. Dengan terujinya koefesien 
korelasi tersebut, maka dapat dinyatakan bahwa 17.64 \% pukulan smash permainan bola voli $(\mathrm{Y})$ dapat dijelaskan oleh variabel power otot tungkai $\left(\mathrm{X}_{1}\right)$. Selanjunya Dari distribusi dengan dk 20 (n-2) dan taraf nyata $\alpha=0.05$ diperoleh t table sebesar 1.73 , dengan demikian jelas bahwa t hitung 2.00 lebih besar dari $t$ tabel 1.73. Dengan demikian dapat disimpulkan bahwa koefisien korelasi antara power otot tungkai $\left(\mathrm{x}_{1}\right)$ dengan pukulan smash permainan bola voli $(\mathrm{Y})$ berarti.

Koefesien Korelasi Power Otot Lengan $\left(\mathrm{X}_{2}\right)$ terhadap Pukulan Smash $(\mathrm{Y})$ Pada Pemain Bola Voli SMA Yayasan Perguruan Rakyat1. Dapat dilihat pada tabel 2. berikut:

Tabel 2. Koefesien Korelasi Power Otot Lengan (X2) terhadap Pukulan Smash (Y) Pada Pemain Bola Voli SMA Yayasan Perguruan Rakyat 1.

\begin{tabular}{|c|c|c|c|c|c|c|}
\hline No & Responden & $\mathbf{X}_{2}$ & $x_{2}{ }^{2}$ & $\mathbf{Y}$ & $\mathrm{Y}^{2}$ & $\mathbf{X}_{2} \mathbf{Y}$ \\
\hline 2 & 2 & 52,89 & 2797,35 & 108,11 & 11687,77 & 5717.93 \\
\hline 4 & 4 & 63,05 & 3975,30 & 97,19 & 9445,90 & 6127.83 \\
\hline 5 & 5 & 46,10 & 2125,21 & 103,35 & 10681,22 & 4764.44 \\
\hline 8 & 8 & 56,27 & 3166,31 & 87,21 & 7605,58 & 4907.31 \\
\hline 9 & 9 & 51,19 & 2620,42 & 91,79 & 8425,40 & 4698.73 \\
\hline 10 & 10 & 42,71 & 1824,14 & 97,11 & 9430,35 & 4147.57 \\
\hline 11 & 11 & 41,02 & 1682,64 & 122,57 & 15023,40 & 5027.82 \\
\hline 12 & 12 & 39,32 & 1538,99 & 106,35 & 11310,32 & 4181.68 \\
\hline 16 & 16 & 63,05 & 3975,30 & 97,96 & 9596,16 & 6176.38 \\
\hline 17 & 17 & 49,49 & 2449,26 & 116,48 & 13567,59 & 5764.6 \\
\hline 18 & 18 & 39,32 & 1546,06 & 83,73 & 7010,71 & 3292.26 \\
\hline 19 & 19 & 50,34 & 2534,12 & 118,46 & 14032,77 & 5963.28 \\
\hline 20 & 20 & 35,93 & 1290,96 & 93,70 & 8779,69 & 3366.64 \\
\hline \multicolumn{2}{|r|}{ Jumlah } & 928.30 & 46270,21 & 1994,64 & 202244,3 & 94321,92 \\
\hline
\end{tabular}

Dengan demikian koefisien korelasi antara power otot lengan $\left(\mathrm{X}_{2}\right)$ dengan pukulan smash (Y) pada pemain bola voli SMA Yayasan Perguruan Rakyat 1 adalah sebesar 0,53.

Dari hasil perhitungan koefesien korelasi $\mathrm{X}_{2} \mathrm{Y}$ diperoleh harga $\mathrm{r}=0,53$ sehingga koefesien determinasinya adalah $(0,53) 2$ x 100\% $=28.09 \%$. Dengan terujinya koefesien korelasi tersebut, maka dapat dinyatakan bahwa 28.09 \% pukulan smash permainan bola voli $(\mathrm{Y})$ dapat dijelaskan oleh variabel power otot lengan $\left(\mathrm{X}_{2}\right)$. Dari distribusi dengan dk $20(\mathrm{n}-2)$ dan taraf nyata $\alpha=0.05$ diperoleh t table sebesar 1.73, dengan demikian jelas bahwa t hitung 2.73 lebih besar dari t tabel 1.73. Dengan demikian dapat disimpulkan bahwa koefisien korelasi antara power otot lengan $\left(\mathrm{X}_{2}\right)$ dengan pukulan smash permainan bola voli (Y) berarti. Terdapat atau tidaknya kontribusi antara power otot tungkai $\left(\mathrm{X}_{1}\right)$ dan power otot lengan $\left(\mathrm{X}_{2}\right)$ terhadap pukulan smash pemain bola voli SMA Yayasan Perguruan Rakyat $1(\mathrm{Y})$, maka r yang diperoleh dari hasil analisis koefisien 
korelasi antar variabel diatas selanjutnya dianalisis dengan rumus koefisien korelasi ganda.

Hasil analisis data di atas, menunjukkan bahwa nilai koefisien korelasi $(r)$ power otot tungkai $\left(\mathrm{X}_{1}\right)$ dan power otot lengan $\left(\mathrm{X}_{2}\right)$ terhadap pukulan smash pada pemain bola voli SMA Yayasan Perguruan Rakyat $1(\mathrm{Y})$ adalah sebesar 0,57.

Dari distribusi dengan $\mathrm{dk} 20(\mathrm{n}-2)$ dan taraf nyata $\alpha=0.05$ diperoleh t table sebesar 1.73, dengan demikian jelas bahwa t hitung 3.01 lebih besar dari t tabel 1.73. Dengan demikian dapat disimpulkan bahwa koefisien korelasi antara power otot lengan $\left(\mathrm{X}_{2}\right)$ dengan pukulan smash permainan bola voli $(\mathrm{Y})$ berarti. Pengujian hipotesis pertama berdasarkan hasil uji korelasi antara $\mathrm{X}_{1}$ dengan $\mathrm{Y}$ diperoleh koefesien korelasi sebesar 0,42. Dari distribusi dengan dk 20 ( $\mathrm{n}-2$ ) dan taraf nyata $\alpha=0.05$ diperoleh $\mathrm{t}$ table sebesar 1.73, dengan demikian jelas bahwa t hitung 2.00 lebih besar dari t tabel 1.73. Dengan demikian dapat disimpulkan bahwa koefisien korelasi antara power otot tungkai $\left(\mathrm{X}_{1}\right)$ dengan pukulan smash permainan bola voli $(\mathrm{Y})$ berarti, maka hipotesis menyatakan terdapat kontribusi antara power otot tungkai terhadap pukulan smash diterima kebenarannya. Pengujian hipotesis kedua berdasarkan hasil uji korelasi antara $\mathrm{X}_{2}$ dengan $\mathrm{Y}$ diperolehkoefesienkorelasisebesar0,53.Daridistribusidengandk20(n-2) dan taraf nyata $\alpha=0.05$ diperoleh t table sebesar 1.73 , dengan demikian jelas bahwa t hitung 2.73 lebih besar dari t tabel 1.73. Dengan demikian dapat disimpulkan bahwa koefisien korelasi antara power otot lengan $\left(\mathrm{X}_{2}\right)$ dengan pukulan smash permainan bola voli (Y) berarti, maka hipotesis menyatakan terdapat kontribusi antara power otot lengan terhadap pukulan smash diterima kebenarannya. Pengujian hipotesis ketiga berdasarkan hasil uji korelasi antara $\mathrm{X}_{1}$ dan $\mathrm{X}_{2}$ dengan $\mathrm{Y}$ diperoleh koefesien korelasi sebesar 0,57. Dari distribusi dengan dk $20(n-2)$ dan taraf nyata $\alpha=0.05$ diperoleh $t$ table sebesar 1.73, dengan demikian jelas bahwa t hitung 3.01 lebih besar dari t tabel 1.73. Dengan demikian dapat disimpulkan bahwa koefisien korelasi antara power otot tungkai $\left(\mathrm{X}_{1}\right)$ dan power otot lengan $\left(\mathrm{X}_{2}\right)$ dengan pukulan smash permainan bolavoli (Y)berarti,makahipotesismenyatakanterdapatkontribusiantarapowerotot tungkai dan power otot lengan terhadap pukulan smash diterima kebenarannya. Untuk menguji hipotesis yang telah dirumuskan tersebut, dapat ditempuh dengan pengujian F-hitung. Dalam hal ini merupakan salah satu cara untuk membuktikan kebenaran atau 
kedudukan suatu hipotesis penelitian yang memiliki dua atau lebih variabel X. Dari perhitungan di atas, diperoleh nilai $F_{h}(F-h i t u n g)=4,16$, sedangkan nilai $F_{t}$ (F-tabel) pada taraf signifikan 95\% dengan derajat kebebasan k/n-k-1 adalah 3,59. Artinya nilai $F_{h}=4,16>$ nilai $F_{t}=3.59$. Uraian tersebut menunjukan bahwa hipotesis yang penulis rumuskan diterima kebenarannya. Hal ini sesuai dengan pendapat Ispardjadi (1988) yang mengatakan bahwa Bilamana F yang kita peroleh sama atau lebih besar dari pada nilai F yang terdapat dalam tabel, maka nilai F yang diperoleh itusignifikan.

\section{PEMBAHASAN}

Berdasarkan hasil penelitian dan pengolahan data tes power otot tungkai dan power otot lengan terhadap pukulan smash pada pemain bola voli SMA Yayasan Perguruan Rakyat 1 yang terdiri dari tiga item tes telah diperoleh hasil sebagaimana terlihat dalam pengujian hiptesis. Hasil pengujian hipotesis pertama menunjukkan bahwa power otot tungkai $\left(\mathrm{X}_{1}\right)$ memberi kontribusi yang signifikan terhadap pukulan smash $(Y)$, dimana hasil pengujian diperoleh nilai $r=0.42$. Dengan demikian otot tungkai memberi sumbangan sebesar $17,64 \%\left(0.42^{2} \times 100 \%\right)$ terhadap pukulan smash. Ini menunjukkan bahwa $17,64 \%$ variasi skor yang terjadi terhadap pukulan smash pemain bola voli SMA Yayasan Perguruan Rakyat 1 dapat dijelaskan oleh power otot tungkai, sehingga kontribusi faktor-faktor lainnya sebesar82.36\%. Hasil pengujian hipotesis kedua menunjukkan bahwa power otot lengan $\left(\mathrm{X}_{2}\right)$ memberi kontribusi yang signifikan terhadap pukulan smash $(Y)$, dimana hasil pengujian diperoleh nilai $r=0.53$. Dengan demikian otot tungkai memberi sumbangan sebesar $28,09 \%\left(0.53^{2} \times 100 \%\right)$ terhadap pukulan smash. Ini menunjukkan bahwa 28,09 \% variasi skor yang terjadi terhadap pukulan smash pemain bola voli SMA Yayasan Perguruan Rakyat 1 dapat dijelaskan oleh power otot lengan, sehingga kontribusi faktor-faktor lainnya sebesar 71,91\%. Hasil pengujian hipotesis ketiga menunjukkan bahwa power otot tungkai $\left(\mathrm{X}_{1}\right)$ dan power otot lengan $\left(\mathrm{X}_{2}\right)$ memberi kontribusi yang signifikan terhadap pukulan smash $(Y)$, dimana hasil pengujian diperoleh nilai $R_{y}, X_{1} X_{2}=0,57$. Dengan demikian power otot tungkai dan power otot lengan memberi sumbangan sebesar $32,49 \%$ $\left(0.57^{2} \times 100 \%\right)$ terhadap pukulan smash. Ini menunjukkan bahwa $32,49 \%$ variasi skor yang terjadi terhadap pukulan smash pemain bola voli SMA Yayasan PerguruanRakyat 1 dapat dijelaskan oleh power otot tungkai dan power otot lengan, sehingga kontribusi 
faktor-faktor lainnya sebesar 67,51 \%. Dari perhitungan hipotesis diperoleh nilai $F_{h}(F-$ hitung $)=4,16$, sedangkan nilai $F_{t}(F-$ tabel $)$ pada taraf signifikan $95 \%$ dengan derajat kebebasan k/n-k-1 adalah 3,59. Artinya nilai $F_{h}=4,16>$ nilai $F_{t}=3 \cdot 59$. Maka power otot tungkai dan power otot lengan memberikan kontribusi yang signifikan terhadap pukulan smash pada pemain bola voli SMA Yayasan Perguruan Rakyat1.

Penelitian ini dilakukan hanya sebatas pembuktian teori-teori yang telah dikemukakan para ahli olahraga, namun demikian penelitian ini diharapkan dapat menjadi bahan masukan yang berarti bagi pengembangan ilmu pengetahuan secara umum dan lebih khusus lagi untuk pengembangan ilmu keolahragaan dalam rangka peningkatan prestasi cabang olahraga bola voli.

\section{KESIMPULAN}

Hasil penelitian dengan pengolahan serta analisis data, maka dapat diambil beberapa kesimpulan sebagai berikut: 1) Terdapat kontribusi yang signifikan antara power otot tungkai dengan pululan smash pada permainan bola voli, hal tersebut ditunjukkan oleh koefisien korelasi sebesar 0.42. Power otot tungkai memberikan kontribusi sebesar 17,64 \% dengan pululan smash pada pemain bola voli SMA Yayasan Perguruan Rakyat1. 2) Terdapat kontribusi yang signifikan antara power otot lengan dengan pululan smash pada permainan bola voli, hal tersebut ditunjukkan oleh koefisien korelasi sebesar 0,53. Kecepatan memberikan kontribusi sebesar 28,09\% dengan pululan smash pada pemain bola voli SMA Yayasan Perguruan Rakyat1. 3) Terdapat kontribusi yang signifikan antara power otot tungkai dan power otot lengan dengan pululan smash pada permainan bola voli, hal tersebut ditunjukkan oleh koefisien korelasi sebesar 0,57 , sehingga secara bersama- sama power otot tungkai dan power otot lengan memberikan kontribusi sebesar 32,49 \% dengan pululan smash pada pemain bola voli SMA Yayasan Perguruan Rakyat.

\section{HAMBATAN DAN KENDALA}

Kami tidak menemukan hambatan dalam penelitian ini.

\section{DAFTAR PUSTAKA}

Ahmadi, Nuril, (2007). Panduan Olah Raga Bola Voli, PT Era Pustaka utama, Solo

Arikunto, Suharsimi, (1991), Prosedur Penelitian Sutu Pendekatan Praktis. PT. Rineka Cipta, Jakarta. 
Bompa.O, Tudor. Terjemahan Buku Theory And Methodology Of Training.

Surabaya : Fakultas Pasca Sarjana Universitas Airlangga Surabaya Beutelsthal, D. (1984). Belajar Bermain Bola Voli.Bandung:Pioneer.

Clenaghan Mc. Dan Rotella Pate. (1993). Latihan Pembebanan: Cv. Bumi Aksara. Jakarta. Greg Brit Brittenham. Ms Kinesiologi. (1996). Latihan Khusus Pemantapan, PT. Raja Grarindo Persada, Jakarta.

Harsono. (1988). Coaching dan Aspek-aspek Psiologi dan Coaching. CV Tamdak Kusuma, Jakarta.

Iqbal, M., Asmawi, M., Tangkudung, J., Dlis, F., \& Saputra, S. A. (2019). Interactive Multimedia Development in Futsal Basic Techniques. Journal of Education, Health and Sport, 9(10), 121-131. https://doi.org/10.5281/zenodo.3491207.

Iqbal, M., Asmawi, M., \& Tangkudung, J. (2019). Investigating the effect of multimediabased interactive basic techniques on futsal exercise variations. Journal of Physics: Conference Series, 1402(7), 077082. https://doi.org/10.1088/17426596/1402/7/077082.

Johnson, (1986). Practical Mensuarement for Evaluation in Physical Education, Publishing campani.

Hidayat, 1. (1992). Pengetahuan Dasar Gerak, Depdikbub, Universitas Terbuka : Jakarta. Lutan, Rusli,dkk (1991). Manusia dan olahraga, TB dan FPOK/ IKIP Bandung Meoloek, Dangsima. (1984). Dasar Fisiologis Kesegaran Jasmani dan Latihan Olahraga. (Editor). FKUI Press:Jakarta.

Nurhasan. (1991). Tes dan Pengukuran Pendidikan Olahraga. Epok Ikip,Bandung. Pate,Russel r. (1984). Dasar-dasar Ilmiah Pelatihan. IKIP Semarang Press: Semarang. Sajoto. Muhammad, (1988), Peningkatan Kondisi Fisik Dalam Olahraga, Dahara Prize : Semarang.

Santoso. (1992). Ilmu Faal Olahraga. IPOK IKIP Bandung Sudjana.(1989). Pengantar Statistic Infrensi. Rajawali, Jakarta.

Suharno, (1981). Pendidikan Jasmani dan Kesehatan, Depdikbub : Jakarta.

Suharto,dkk (2000). Pedoman Dan Modul Pelatihan Kesehatan Olahraga Bagi Pelatih Olahragawan Pelajar, Depdiknas:Jakarta. 
Widaninggar, dkk.(2003). Tes Kesegaran Jasmani Indonesia, Depdiknas:Jakarta Wirjasantosa, Ratal (1984). Supervise Pendidikan Olahraga, Universitas Indonesia Prees, Jakarta.

Widiastuti, (2011). Tes dan Pengukuran Olahraga, PT. Bumi Timur Jaya, Jakarta 


\section{LAMPIRAN}

\section{Informasi Tentang Penulis:}

Kosharyanto Pratomo:

Email: Kosharyantopratomo26@gmail.com; Program Studi Pendidikan Olahraga STKIP Kusuma Negara Jakarta; Alamat: Jl Raya Bogor Km. 24 Cijantung, Jakarta Timur, 13770. DKI Jakarta, Indonesia.

\section{Muhammad iqbal, M.Pd:}

Email: m_iqbal@stkipkusumanegara.ac.id;OrchidＩD: https://orcid.org/0000-0002-97479374; Program Studi Pendidikan Olahraga STKIP Kusuma Negara Jakarta; Alamat: Jl Raya Bogor Km. 24 Cijantung, Jakarta Timur, 13770. DKI Jakarta, Indonesia. 